\title{
REVIT ARCHITECTURE 2013 SOCIALIZATION FOR VOCATIONAL SCHOOL IN SMK 4 TANGERANG
}

\author{
Harfa Iskandaria, Anggraeni Dyah, Karya Subagya \\ Universitas Budi Luhur, Indonesia. \\ harfa.iskandaria@budiluhur.ac.id
}

\begin{abstract}
High school in Indonesia has two types, specifically senior high schools and vocational schools (SMK). Vocational high schools in Indonesia have a lot of education focus which aims to provide education to their students so they can work immediately. One of the vocational schools in Indonesia is the Tangerang 4 Vocational High School which focuses on education in engineering. One of the engineering scopes at SMK Negeri 4 Tangerang is "Drawing Technique for Building" (Teknik Gambar Bangunan). "Drawing Technique for Building" is a vocational class that specializes in learning how to draw techniques for houses and buildings. As vocational students of "Building Drawing Technique", each student must learn how to draw techniques according to ISO standards complete with various etiquettes in manually, after proficient in drawing manually, students must learn AutoCAD, an software for drawing because this becomes the main competency as students "Building Drawing Techniques". To increase the capacity and capabilities of its students at SMK 4 Tangerang, the Budi Luhur University Architecture Study Program introduces one of the software related to building drawing The software introduced in Revit Architecture version 2013. Revit Architecture 2013 is a software that aims to create building construction designs for architects and supports the concept of BIM (Building Information Modeling). The output of this socialization is that students of SMK Negeri 4 Tangerang understanding about software for drawing techniques other than AutoCAD and various conveniences when drawing with Revit Architecture 2013 software
\end{abstract}

Keywords: Revit Architecture; Engineering drawings; BIM; Vocational School

\section{INTRODUCTION}

The house as one of the primary needs for humans generate a motivation to always get a house to live in various ways such as buying a house, rent a house either a landed house or flat, In addition to housing, human space for activities and work also requires buildings that are appropriate and suitable for the building's use function. An architect is a certain person who is able to build various kinds of buildings, with various mathematical calculations and examine aspects of humanity as well. architects become one of the promising professions as long as humanity needs buildings with a variety of functions.

Although an architect has the ability to plan a building, the presence of reliable drafter drawings also takes into consideration how a technical drawing for a building can fulfill the requirements and comply with ISO standards. The presence of a drafter in addition to a junior architect, drafter images can be found in drawing engineering class students at vocational schools. These students have the primary competence to draw according to ISO standards both manually and digitally using AutoCAD software.

Jobs that require drafter include architecture, mechanical engineering, civil engineering to the manufacturing industry. In the beginning, a drafter always sat at the drawing table and used drawing tools manually such as pencils, drawing pens, rulers, compass, protractors, triangle rulers in order to produce images that match ISO requirements. As technology develops in the field of computers, the task of a drafter is much easier because it can use a variety of drawing software such as AutoCAD, 3D Max, SketchUp, Archicad, and Revit Architecture.

With the computerized depiction of the world of architecture has the easiness when it will make revisions, image reproduction and ease in transferring data in the form of digital images can be done faster and more timely. A predicate drafter is a person who works in the field of making drawings that can prepare technical working drawings so that images can be easily understood by others, especially when entering the production process or development stage. Before 1980 not everyone could become a drafter because every drafter had to go through a formal education process such as a vocational drawing school or become a student at a university in the engineering faculty.

In 1980 the discovered of a computer program for drawing under the name CAD (Computer-Aided Design) by a company called Autodesk. After the discovery of CAD, the ease of being a drafter can be achieved, even though 
someone's ability to draw manually is not capable, then with the help of CAD, everyone can draw. The good news with the help of CAD drawings produced is far more precise than drawing manually. (Sholeh, 2012)

$\mathrm{CAD}$ history has been going on for 34 years, at first $\mathrm{CAD}$ was only in the form of lines with $\mathrm{X}$ and $\mathrm{Y}$ axes to produce 2-dimensional images. Until 1993 Autodesk introduced 3D CAD, a DOS-based computer program with $\mathrm{X}, \mathrm{Y}$ and $\mathrm{Z}$ axes. After the development of $3 \mathrm{D}$ CAD is the beginning of the development of modeling and simulation of an industrial or building product before the building is made.

\section{TARGET OF SOCIALIZATION}

The target of this socialization is SMK Negeri 4 Tangerang which is a vocational school with the address at Jl. Veteran No 1A, Kelurahan Babakan, Tangerang District, Tangerang City Banten Province. This vocational school has a basic education in engineering, this 4 vocational school in Tangerang with nine majors consisting of:

1. Software Engineering

2. Concrete \& Construction Techniques

3. Building Drawing Techniques

4. Survey and Mapping Techniques

5. Electric Power Installation Techniques

6. Industrial Automation Engineering

7. Machining Techniques

8. Mechanical Drawing Engineering

9. Industrial Machinery Maintenance Techniques

Building Drawing Technique is one of the vocational sciences in SMK Negeri 4 Tangerang. Although based on engineering, the building drawing engineering class only applies two main software namely AutoCAD and 3D Max, while for other devices such as sketch up, it is only used as supporting software. The building drawing technique at this school is called TGB class, TGB class there are six classes consisting of class X TGB 1, X TGB 2, XI TGB 1, XI TGB 2, XII TGB 1 and XII TGB 2.

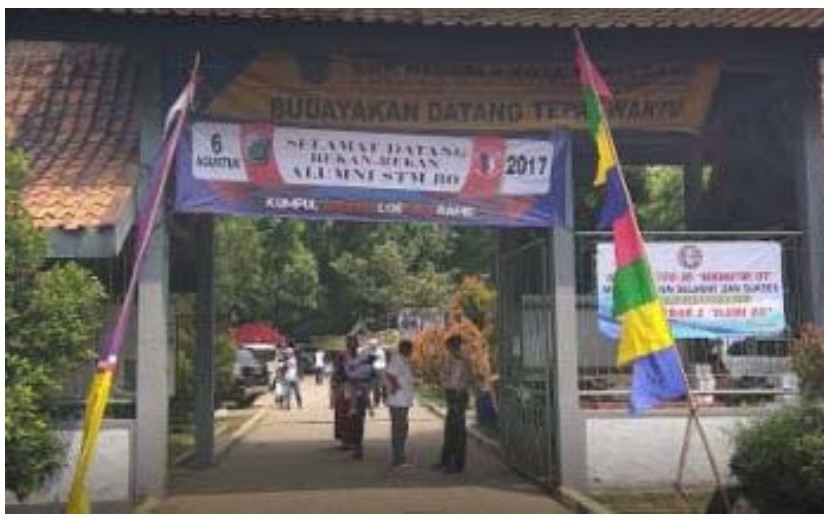

Fig. 1. Main gate SMK Negeri Tangerang 4

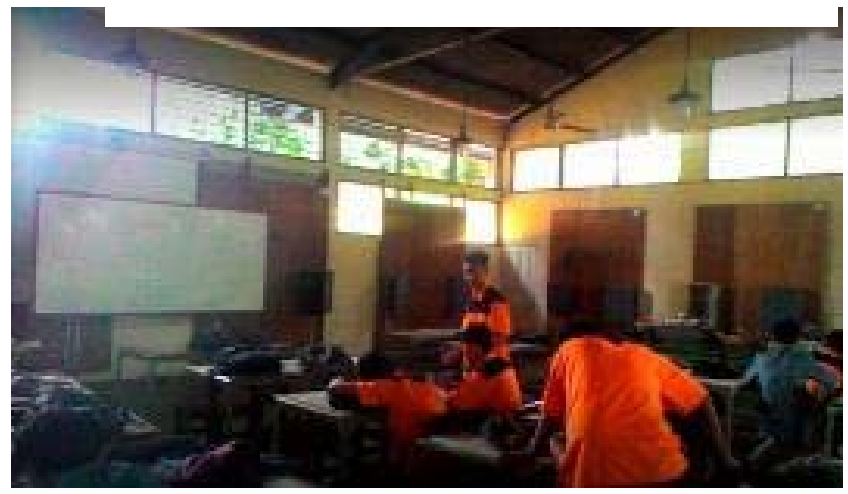

Fig. 2. Classroom in SMK Negeri Tangerang 4 


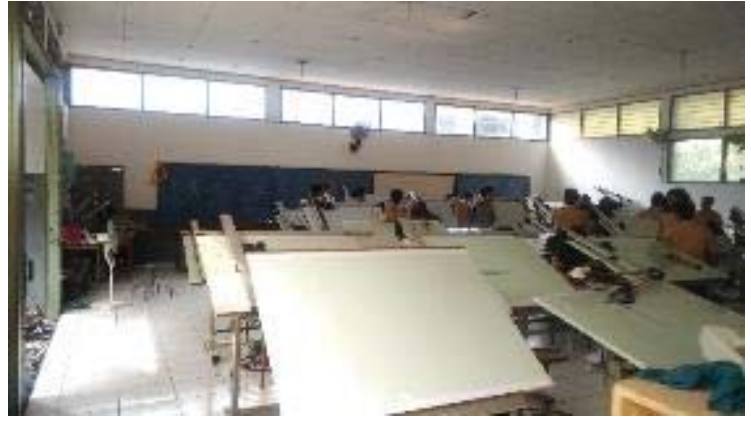

Fig. 3. Drawing classroom equipped with drawing tools

The target of this socialization is students of class XII TGB 1 and XII TGB 2, this is because students of Building Drawing Engineering in class XI have gained the basis of manual engineering drawing and Autodesk AutoCAD as the main competencies. Based on interviews with the Head of the Building Drawing Engineering Department Ahmad Dani Sujai, S.T., all students from the TGB class did not know about the Revit Architecture software. based on the interview, before the socialization activity is carried out, materials must be prepared so that various kinds of basic commands from Revit Architecture are carried out.

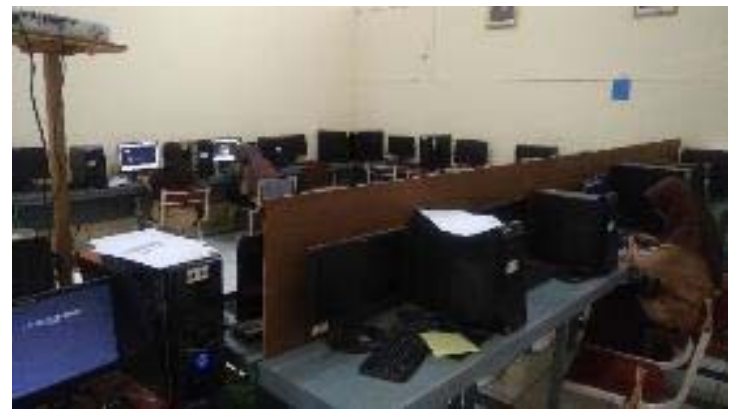

Fig. 4. Drawing classroom equipped with computers

\section{IMPLEMENTATION OF REVIT ARCHITECTURE SOCIALIZATION ACTIVITIES}

The method used in the Revit Architecture socialization was carried out in two steps. The first step is to provide socialization by making a brief booklet about Revit Architecture, including the types of computer requirements that can be used for Revit Architecture software. In this first step the implementation of the socialization was carried out in the Budi Luhur University computer laboratory room, this was due to the ability of computers at Budi Luhur University that met the minimum specifications of Revit Architecture.

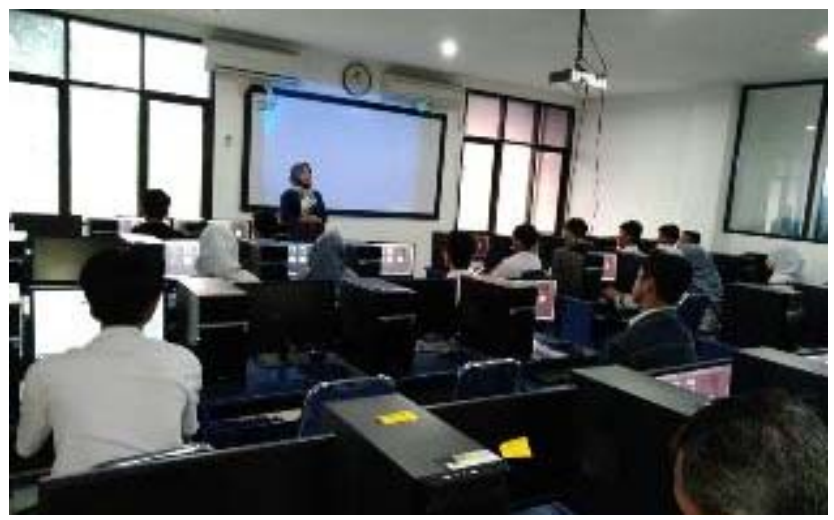

Fig. 5. The socialization conditions opened by the architectural study program 


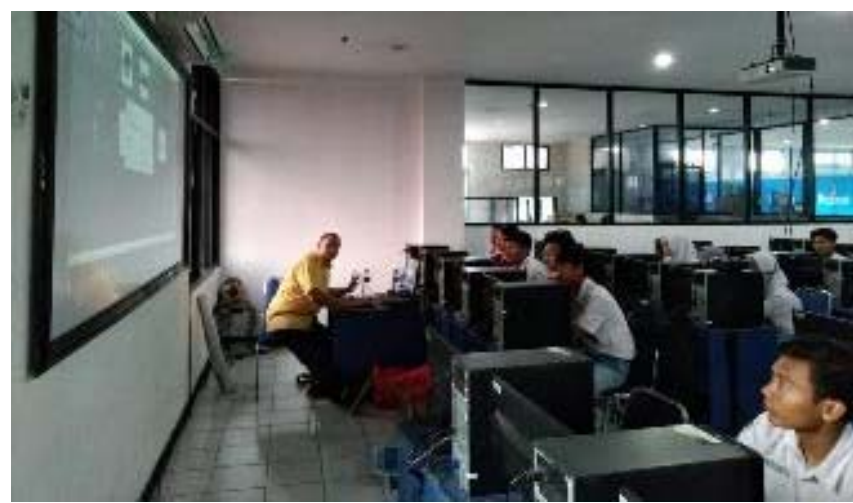

Fig. 6. The socialization was perform by an architecture lecturer

Following are the stages of implementing Revit Architecture socialization:

1. The initial material is an introduction user interface of Revit Architecture 2013.

2. The next discussion is an explanation of adjust units and adjust the scale of images in Revit Architecture.

3. The next explanation is to provide understanding to vocational students related to the advantages and disadvantages of Revit Architecture including:

a. Advantages of Revit Architecture

i. Modeling virtual buildings: by using virtual buildings, the explanation of the drawing is no longer about the lines and the $\mathrm{X}$ and $\mathrm{Y}$ axes, but each line that is created can be directly applied in the form of 3 dimensions by the program itself.

ii. Knowing building information.

Based on the function of Revit Architecture namely BIM (Building Information Modeling), with the function of the building the drafter must enter various building-related information such as the price of material per cubic meter, the number of door needs, the number of window needs and even the wall type can also be known in Revit Architecture (Chandra, 2012).

iii. Ease of migrating peer Autodesk products.

b. Disadvantages of Revit Architecture

i. Requires the latest computer specifications.

ii. the function of Revit Architecture is the BIM (Building Information Modeling) of the building's function, the drafter must enter various information manually as a whole from the foundation to the roof.

The next explanation related to Revit Architecture is the ease in inserting objects of doors, windows, to the picture complementary furniture that has been provided in the Revit Architecture library. The next socialization was to introduce how to change the appearance of two dimensions into three dimensions, incorporate material motifs in building modeling, introduce the rendering system in Revit Architecture. After all the main functions have been socialized, the next step is to guide how to transfer images by exporting/importing from Revit Architecture to other AutoDesk products such as AutoCAD. (Zainal, 2017)

The second step is evaluation, evaluation is carried out in the form of drawings that must be done in practice using Revit architecture, based on the results of the evaluation of 48 students who participated in this socialization, all students can draw using Revit Architecture. 


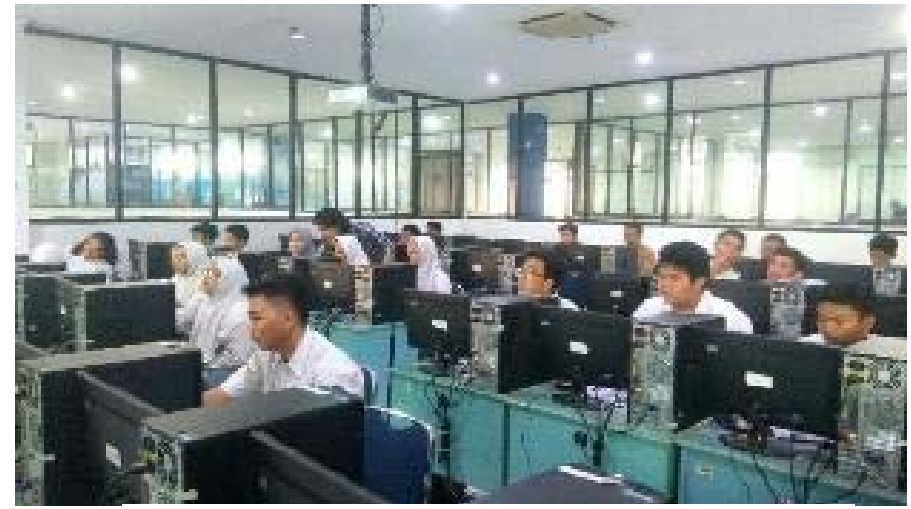

Fig. 7. The evaluation phase is assisted by architecture students

\section{CONCLUSION}

Revit Architecture is software that can make it easier for the drafter to complete technical work drawings. in addition, this software can simulate buildings in the form of modeling and can estimate the volume used which is needed to calculate future budget plans. All Vocational School 4 Tangerang students after the Revit Architecture socialization, were quite enthusiastic in learning Revit architecture software, this can be known after the socialization, many students asked about computer specifications that could be installed by Revit Architecture software.

\section{REFERENCE}

Chandra, Handi. (2012). 7 Jam Belajar Interaktif Revit Architecture 2012 Untuk Orang Awam. Maxikom, Palembang, Indonesia.

Sholeh, M. (2012). Belajar Otodidak AutoCAD 2D dan 3D.Informatika, Bandung, Indonesia

Zainal Abdi, M. (2017). Revit Untuk Desain Bangunan. Modula, Bandung, Indonesia. 